$\xi=$ 峝

\title{
Environmental Impact Assessment: Integrated Evaluation of Bridge Construction Project in Bangladesh
}

\author{
Irteja Hasan ${ }^{1}$ *, Milton Shaha ${ }^{2}$, Md. Shafiqul Islam ${ }^{1}$, Md. Sirajul Islam $^{3}$, Md. Solayman ${ }^{4}$, \\ Miraz Hossen ${ }^{4}$, Md. Humayun Kabir ${ }^{1}$ \\ ${ }^{1}$ Assistant Consultant (Environment), EQMS Consulting Ltd, Banani, Dhaka -1213, Bangladesh \\ ${ }^{2}$ Department of Disaster Risk Management, Patuakhali Science and Technology University, Dumki, Patuakhali-8602, Bangladesh \\ ${ }^{3}$ Professor, Department of Environmental Science and Resource Management, Mawlana Bhashani Science and Technology Univer- \\ sity, Santosh, Tangail-1902, Bangladesh \\ ${ }^{4}$ Faculty of Disaster Management, Patuakhali Science and Technology University, Dumki, Patuakhali-8602, Bangladesh
}

*Corresponding author E-mail: irteja07@gmail.com

\begin{abstract}
Environmental Impact Assessment (EIA) may provide a mechanism for executing sustainable development and it is also becoming a very significance revision before authorizing of any project plan. EIA helps to decision making process whether the project is beneficial or harmful effects for the environment. Both on site and off site environmental impacts can be reduced through undertaking EIA for any bridge construction activities. This paper mainly concentrates on to find out potential environmental impact during the construction, operation and maintenance phase of the project using different matrix method. It also finds out the effective mitigation measures of the adverse impacts that will be helpful for the surrounding environment. Primary data were collected from field survey, focus group discussion. Most of the impacts and other consequences are identified based on public perception and the interview of the key personnel's. Secondary data were also collected for conducting the research. The study found that the bridge is connecting three regions (Bauphal, Patuakhali and Barisal) and it will be a great achievement for the local coastal community. This new bridge project will not only increase the communication facilities but also other facilities such as economic flow, medical facilities etc. The EIA study founds some major negative Impacts such as loss of land and resettlement, loss of aquatic habitat, loss of local trees varieties, loss of agricultural lands, loss of vegetation, potential impact on ecological resources, impact on fish migration etc. But analyzing the overall impact of the environment, the EIA study found that that the possible negative impact is not so high and the project can be implemented. Different environmental management plans are suggested for reducing the potential negative impact of the bridge construction project.
\end{abstract}

Keywords: Environmental Impact Assessment (EIA); Mitigation; Bridge; Bangladesh.

\section{Introduction}

Bangladesh is a major developing country that is particularly vulnerable to different type's environmental change due to climate change and anthropogenic causes [7], [11]. Since independence in 1971, Bangladesh has initiated a number of environmental rules and regulations [5-8] that is prominent in the global push for sustainable development goals. [12]. Environmental impact assessment (EIA) has a play a vital role in achieving these goals [1], [9], [10], and [11]. However, EIA has some limitations but it is important for the country to improve on these limitations with an aim to building a robust of EIA system for sustainable development. EIA has recently been made known to the country by the Environment Conservation Act, 1995 and the Environment Conservation Rules, 1997 but there are a number of inadequacies with the current process [2], [3], [4]. EIA identify the need, gap and mitigation measures for any developmental activities. The proposed Bridge construction project is located at Baga ferry Ghat under Patuakhali District. This Bridge is approximately $294 \mathrm{~km}$ from Dhaka, Bangladesh. The Bridge traverses the Galachipa River and the river takes from Lohalia River near Patuakhali town and flows as Galachipa River. The proposed Bridge will connect Bauphal, Kalaia with Ptuakhali district and
Barisal division and others parts of Bangladesh. It will also make easier the Dhaka Bauphal route than before. Bauphal and Kalia Bazar are economically important areas from the ancient time. After the completion of the bridge the economic condition of southern region especially Baga, Bauphal and Kalia will be rapidly developed.

The proposed Bridge will save both time and money for transportation of people and goods services. New employment opportunities will be generated for the local people. Now the ferry service has given connectivity with other places. However, at the ferry point, people have to wait average one and half hour or more. After the completion of the bridge, the commercial vehicles will be able to give more trips and people will be able to reach their destination within a short time. At the time of natural calamity, the ferry service is disrupted which hampers the economic and social activities severely. This project will play a significant role for the development of southeastern part of Bangladesh, especially Baga, Bauphal, Kalia. Due to this project, the communication system of this area will be developed which will accelerate the development of these areas. The socio-economic status of these areas will be rapidly improved. This project has a very negligible effect on environment. This project will enhance the export and import system that will flourish the economic status of the area. There are four categories 
of projects: green, orange A, orange $\mathrm{B}$ and red with respectively no, minor, medium and severe environmental impacts. For the red category of projects, a full EIA is required. All regional and national highway, railway and bridge projects of over $100 \mathrm{~m}$ length fall in the red category. The orange B category includes feeder and district roads and bridges under $100 \mathrm{~m}$ length [2]. The proposed Baga Bridge is $700 \mathrm{~m}$ long. So, it is included in the red category. That's why Environmental Impacts Assessment should include the prediction, evaluation and mitigation of environmental impacts based on the characteristics of project. The main purpose of this study is to find out the adverse environmental impact during the construction operation and maintenance phase of the project. The precise purpose of the study is:

- To find out potential environmental impact during the construction, operation and maintenance phase of the project

- To propose effective mitigation measures of the adverse impacts from the bridge construction in the project area

\section{Methodology of the study}

Initially a field visit was conducted in the project area to identify the project and location. Participatory Community Risk Assessment (CRA), Rural Appraisals (PRAs), Focused Group Discussions (FGDs) and interviews with key informants were conducted to collect data and information. In the study area, one hundred and Twenty (120) households were selected for conducting the EIA research. The study only focused on one hundred and Twenty households that were purposively selected for directing the research. The selected respondents' households were not representative of a larger sample, but they were cases which demonstrated different contexts. Moreover, different extreme poor household's compositions such as female headed, male headed, and female managed, larger family and religious minorities were also kept in mind when selecting the sample. Ten focus group discussions were organized for conducting the research. These groups were also comprised of men and women. This method was very effective to authenticate the opinion of communities and key informant's personnel. It also provided useful information in a short period of time for understanding the real conditions of local communities in the study area. The research also conducted key informants interview such as four Key Informants Interviews among the local representatives and School teachers and seven Key Informants Interview among NGO Officers. In order to get socio-demographic information of selected households, baseline surveys have been used for shepherding the research. Similarly, during qualitative field work, the study also collected detailed information on their socio demographic status after different disasters. This information helped to compare change over time.

Local knowledgeable persons including community representatives, traders, teachers, and political leaders were interviewed individually to know the perception about the project. They were also requested to highlight possible solutions that the project should bring about as per their indigenous knowledge and experiences. The baseline environmental condition of the project area was drawn according to the information collected from secondary and primary data sources through literature review, field investigations and consultations with different stakeholders. For primary data collection five focus group discussion, hundred household surveys and twenty KII were conducted. The baseline data of water resources, land resources, agriculture, livestock, fishery, ecosystems and socio-economic resources were collected from different internet sources. The matrix has been used for the evaluation of the bridge construction projects supported by extensive field checks and surveys. The selected sites were existing namely Baga Bridge project in Patuakhali district. These EIA reports of building construction projects were critically reviewed with ground observations using different building construction projects parameters.

\section{Description of the project location and ac- cess ways}

The proposed project is located at Baga ferry Ghat of Bauphal Upazila. The project site lies within geographical coordinates $22.42^{\circ} \mathrm{N}$ and $90.45^{\circ} \mathrm{E}$. The location is easy communicated both in road and river ways. Baga is located near Patuakhali Sadar and their distance is $28.8 \mathrm{~km}$ by road and $15 \mathrm{~km}$ water ways. The proposed project will be constructed on the river Galachipa at $294 \mathrm{~km}$ of Dhaka-Mawa-Bhanga-Barisal-Labukhali-Pagla-Baga road and 200 $\mathrm{km}$ from Dhaka by water way.

\subsection{Project type}

Under the Environmental Conservation Rules (1997), a classification system was established for development projects and industries on basis of the location, the size and the severity of potential pollution. There are four categories of projects: green, orange A, orange $\mathrm{B}$ and red with respectively no, minor, medium and severe environmental impacts. For the red category of projects, a full EIA is required. All regional and national highway, railway and bridge projects of over $100 \mathrm{~m}$ length fall in the red category. The orange B category includes feeder and district roads and bridges under $100 \mathrm{~m}$ length [2]. The proposed Baga Bridge is 700m long. Therefore, it is included in the red category. That is why Environmental Impacts Assessment should include the prediction, evaluation and mitigation of environmental impacts. Based on the characteristics of project and an Environmental Man-agreement and Monitoring Plan will be prepared.
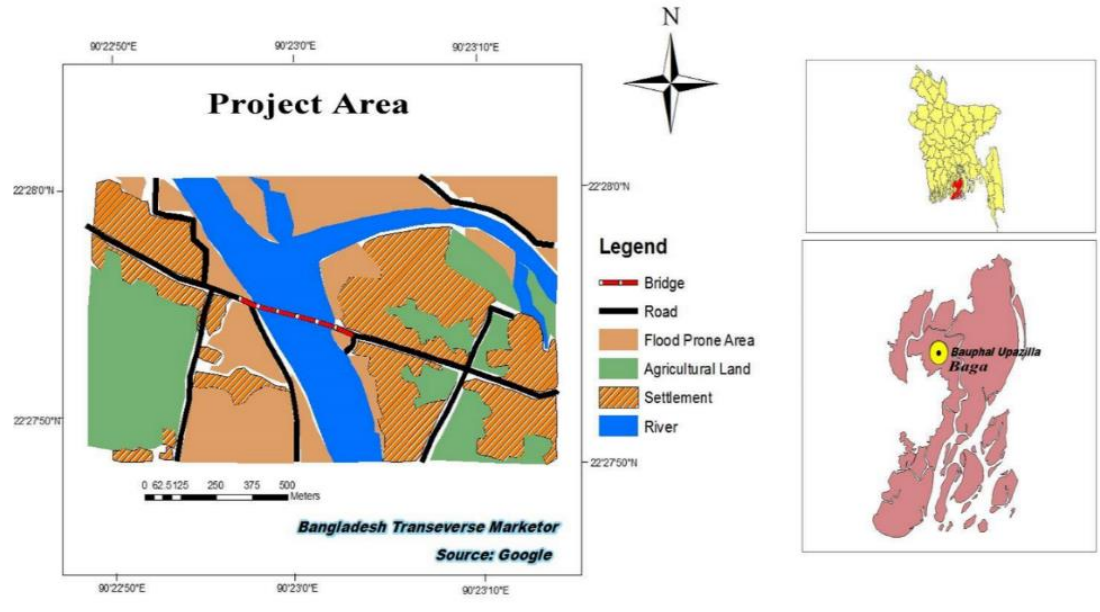

Fig. 1: Project Location 


\section{Results and discussion}

\subsection{Environmental impact and mitigation measure}

For the construction of the project about 750 acres land acquisition will be needed where included agricultural land, forest land, flood plain and wetland. Due to this land acquisition many species endangered species, natural habitats, agriculture and fish production will be threatened which make it as a critical issue of the project. A social forest is situated near the Baga ferry Ghat. Due to the construction of approach road and construction yard this forest land will be destroyed. As a result of this destruction many natural habitats such as bird nests, honey comb and the habitat of wild animals will be hampered. Piling and some other constructions activity will produce a lot of vibration. This vibration has a negative impact on fish migration and the breading of porpoise. Beside this, vibration has a negative impact on human health. For all of these reasons it is critical issues.

Char land and floodplains will be used for construction purpose. For being a nutrient and insects enriched land, it is preferred by the migratory birds. As a result of these losses of land, tease migratory birds will lose their roaming ground. Due to the implementation of the project many people will lose their livelihood such as the hawker of ferry Ghat, boat man of Galachipa river, Shopkeepers of the both side of the ferry Ghat. It is very hard to change the livelihood of hawker and boat man. Construction materials will be mix with air and water at different phases as of construction. Emission of dust and different gases such as $\mathrm{CO}, \mathrm{SO}_{2}$ will pollute the air. Construction water and unused materials will increase the turbidity of river water which is very much harmful for the breading of fish. Huge amount of noise will generate by mobilization of different construction materials which. This noise will be harmful for the communication and breading of porpoise. Beside this, these noises have a harmful impact on the health of workers. Due to the improper disposal of waste the odder and other gases will be mixed with air which will pollute the air. Beside this, the mixing of leachate and other types of waste will pollute the water which is very harmful for the fish and other aquatic species. As a result of dredging the turbidity of the river water will be increased this has a negative impact on fish and other aquatic species and their breading process. Due to sloping and channel modification the soft sedimentation will be removed which will hamper the aquatic habitat of river bed. For the construction of the bridge some agricultural lands will have to be used. As a result, some farmers who are only depended on agriculture will lose their livelihood and it will become very hard for them to find alternative livelihood. Some households are situated in the project area which will have to be displaced due to the construction of the project. When resettlement will be provided they will face many problems as a result of new environment, culture and loss opportunity of livelihood. For the construction of the project many wetlands will be filled. As a result, many endangered fish species, amphibians and nematodes will be destroyed. Due to these losses of wetlands annual fish production will be reduced. When the current of the river is interrupted by the pier of the bridge it causes scours. But it is not the main cause of scouring because in most causes the deepest scour is created by river channel.

Detailed Examination of Unresolved Issues

\section{1) Project location}

The project area is a low laying area which is frequently flooded by tidal flood. As it is situated southern area of Bangladesh near the coastline, it is often affected by severe cyclone, storm surge. River erosion is also a great problem of the project. The location of the project is situated in a remote area so transportation of project goods is quite difficult.

\section{2) Emission of gases from bituminous}

The design of the bridge includes the approach road surface of the main bridge and bituminous will be needed for their construction. This bituminous will emit different harmful gases such as $\mathrm{SO}_{\mathrm{x}}$ and $\mathrm{CO}_{\mathrm{x}}$

\section{3) Dust production}

The bridge design includes site preparation, construction of approach road, main bridge, toll plaza and yard. During construction of the part of the design a huge amount of dust will be produced. Beside this, a huge amount dust will be produced as a result of vehicle transportation.

\section{4) Noise}

Noise will be generated in every stage of the project. During the construction stage, noise will be produced by handling of equipment, wielding, piling construction, transportation of vehicle etc. More over a huge amount of noise will be produced in the operational stage due to the transportation of vehicles.

\section{5) Emission of gases from Vehicles}

In the construction stage different harmful gases will be emitted during the transportation of different construction materials. After the completion of the project a huge amount of gases will also be produced due to vehicles transportation.

\subsection{Pre-construction stage excessive emission of gases into the environment}

During construction different types of gases will be emitted for example during the burning of bituminous $\mathrm{CO}_{2}, \mathrm{SO}_{2}$ etc. will be emitted. A huge amount of dust will be produced during different construction activities such as transportation of construction materials, handling of construction equipment and materials. Due to the lack of proper waste disposal system odor and some other gases will emit which will enhance air pollution.

\subsubsection{Vibration}

Especially pile driving and some other activities will generate vibration. Vibration has a negative impact on fish habitat. Breading of different fish species will be hampered by vibration. Beside this, people's health will be affected by vibration.

\subsubsection{Environmental impact assessment using the leopold ma- trix}

Impact factors have been evaluated separately for each environmental component relevant for the scope of this study, and scored on a scale from 0 to 5 for impact magnitude, according to the following scale:

0-No observable effect, 1-Low effect, 2-Tolerable effect, 3- Medium high effect, 4-High effect, 5- Very high effect (devastation)

Table 1: Preconstruction Stage Magnitude of Impact Matrix 




Source: Modified from FAO (1996).

\subsection{Construction stage}

\subsubsection{Physical components}

Water will be mainly affected by disposal of dredge materials and dredging for slope preparation and overall impact is tolerable. Owing to excavation of sediments from the river bed in a dredging process degrades the water quality. The suspended sediment load and turbidity of a river are increased during the removal of bed or bank material and as a consequence of water quality such as temperature is affected (Stollenwerk, 2014). Air will be mainly affected due to clearing of site. Site preparation in the construction time may require vegetation clearance stripping off of overburden material, ground leveling and compaction. But the average impact is very low. Land acquisition and earth filling will mainly affect the land and the overall effect is tolerable. Noise will be mainly generated as a result of mobilization of equipment and others materials but the overall impact is very low. Excessive vibration will be generated due to earth filling and compaction and the average impact of vibration is very low.

\subsubsection{Biological components}

Land acquisition, mobilization of equipment's and clearing of sites will severely affect the flora and fauna diversity but the overall impact is tolerable. Due to earth filling and compaction and land acquisition a large number of wetlands will be filled and the overall impact is tolerable. Char lands will be mainly impacted by land acquisition but the overall impact is tolerable.

\subsubsection{Socio-cultural components}

Because of land acquisition, clearing of sites, removing of top soil and construction of embankment the land scape of the project area will be changed and the overall impact is tolerable. The impact of different activities on health, safety and hygiene is low except mobilization of equipment's, construction materials/vehicles, so the average effect is very low. The economy will be hampered by land acquisition but the entire impact on economy is very low. The probability of accident is preconstruction stage is very low.

Table 2: Construction Stage Magnitude of Impact Matrix

\begin{tabular}{|c|c|c|c|c|c|c|c|c|}
\hline \multicolumn{9}{|c|}{ Project Activities } \\
\hline & $\begin{array}{l}\text { Envisaged Im- } \\
\text { pact Factors }\end{array}$ & $\begin{array}{l}\text { Disposal of } \\
\text { wastes }\end{array}$ & $\begin{array}{l}\text { Clearing } \\
\text { of sites }\end{array}$ & $\begin{array}{l}\text { Removing } \\
\text { of top soils }\end{array}$ & $\begin{array}{l}\text { Earth filling and com- } \\
\text { paction for road em- } \\
\text { bankment }\end{array}$ & $\begin{array}{l}\text { Sum of IF values by } \\
\text { types and bio. compo- } \\
\text { nents }\end{array}$ & $\begin{array}{l}\text { Average } \\
\text { values }\end{array}$ & IF \\
\hline \multirow{5}{*}{ Physical } & Water & 2 & 1 & 1 & 1 & 4.15 & 0.83 & \multirow{10}{*}{$\begin{array}{l}0.63 \text { (Ac- } \\
\text { ceptable) }\end{array}$} \\
\hline & Air & 2 & 2 & 0 & 1 & 5.00 & 1.00 & \\
\hline & Land & 1 & 1 & 1 & 1 & 4.00 & 0.80 & \\
\hline & Noise & 1 & 0 & 0 & 1 & 2.00 & 0.40 & \\
\hline & Vibration & 2 & 1 & 1 & 1 & 5.00 & 1.00 & \\
\hline \multirow[t]{4}{*}{$\begin{array}{l}\text { Biologi- } \\
\text { cal }\end{array}$} & $\begin{array}{l}\text { Flora Diver- } \\
\text { sity }\end{array}$ & 1 & 3 & 1 & 1 & 6.00 & 1.20 & \\
\hline & $\begin{array}{l}\text { Fauna Diver- } \\
\text { sity }\end{array}$ & 1 & 1 & 0 & 0 & 2.00 & 0.40 & \\
\hline & Wetland & 2 & 1 & 1 & 1 & 5.00 & 1.00 & \\
\hline & Char land & 1 & 0 & 1 & 0 & 2.00 & 0.40 & \\
\hline $\begin{array}{l}\text { Socio- } \\
\text { Cultural }\end{array}$ & Landscape & 1 & 0 & 1 & 1 & 3.00 & 0.60 & \\
\hline
\end{tabular}




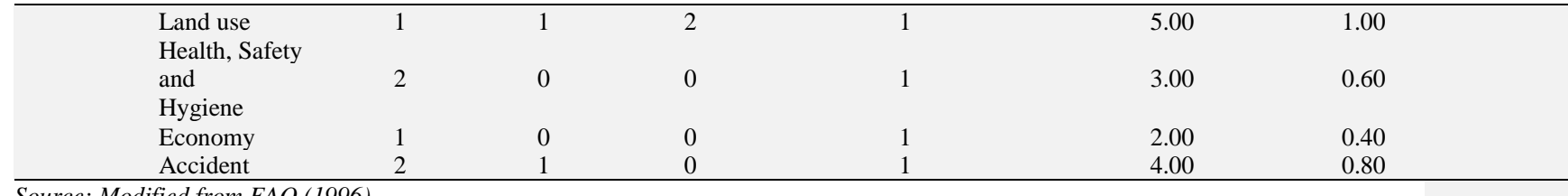

The average assessment effect of cumulative impact factors on environmental components is 1.19 . So, the overall impact of different project activities on physical, biological and socio-cultural components is low. In the preconstruction stage the water, land, flora and fauna diversity, landscape and land use pattern will be mainly affected by different construction activities. So, during construction the authority should be aware of it and take proper mitigation measure for reducing the harmful impact.

\subsection{Operation and maintenance stage impact}

\subsubsection{Physical components}

In the construction stage, the water quality will be mainly affected by the construction of substructure and disposal of wastes and the average impact on water is low. During black carpeting air will be mainly polluted as a result of the gases emitted from bituminous. The air quality will be affected during the construction phase with the emission of dust particles from machinery like excavators, electric grinders and equipment. The substance, which will most significantly contribute to air pollution, will be particulate matter $\left(\mathrm{PM}_{10}\right)$ may cause health hazards when inhaled in significant amounts and can also reduce the visibility. But the general effect is low. Land acquisition will be required for the construction of super structure, clearing of sites, earth filling and compaction etc. the overall impact on land low. In the construction stage, a huge amount of noise will be produced on account of mobilization of equipment, construction of super structure; mobilization of construction materials, vehicles etc. and the overall impact is tolerable. The noise involved during the construction phase will be the result of operation of excavators, Lorries and heavy machinery like electric grinders. Owing to construction of substructure the minimum vibration is tolerable.

\subsubsection{Biological components}

Clearing of sites will adversely affect the flora diversity. Construction of superstructure and improper disposal of waste will also affect the flora and fauna diversity but the overall effect on flora and fauna diversity is low. In the construction state, the impact on wet land is negligible and char land will be mainly used for construction of substructure.

\subsubsection{Socio-cultural components}

Owing to construction of superstructure the landscape of the project site will be impacted but the overall effect is low. Land use pattern will be changed by the reason of construction of superstructure, road and clearing of sites and the overall impact on land use is tolerable. Disposal of waste has a great impact on health, safety and hygiene but the average impact is low. Due to construction of superstructure and road structure, the local economy will be impacted but the overall impact is very low. There is a very less probability of accidents during construction

Table 3: Operation and maintenance Stage Magnitude of Impact Matrix

\begin{tabular}{|c|c|c|c|c|c|c|c|}
\hline & \multirow[b]{3}{*}{$\begin{array}{l}\text { Envisaged Impact } \\
\text { Factors }\end{array}$} & \multirow[b]{3}{*}{ Main Bridge } & \multicolumn{5}{|c|}{ Project Activities } \\
\hline & & & \multicolumn{5}{|c|}{ Operation and Maintenance Stage } \\
\hline & & & River Training Works & Approach roads & $\begin{array}{l}\text { Bridge } \\
\text { end facili- } \\
\text { ties }\end{array}$ & $\begin{array}{l}\text { Sum of IF values by } \\
\text { types and bio. com- } \\
\text { ponents }\end{array}$ & $\begin{array}{l}\text { Average } \\
\text { values }\end{array}$ \\
\hline \multirow{5}{*}{$\begin{array}{l}\text { Physical } \\
\text { compo- } \\
\text { nents }\end{array}$} & Water & 1 & 3 & 1 & 1 & 6 & 1.50 \\
\hline & Air & 3 & 2 & 1 & 1 & 7 & 1.75 \\
\hline & Land & 0 & 0 & 0 & 1 & 1 & 0.25 \\
\hline & Noise & 3 & 2 & 2 & 1 & 8 & 2.00 \\
\hline & Vibration & 2 & 0 & 1 & 0 & 3 & 0.75 \\
\hline \multirow{4}{*}{$\begin{array}{l}\text { Biologi- } \\
\text { cal } \\
\text { Compo- } \\
\text { nents }\end{array}$} & Flora Diversity & 0 & 0 & 1 & 0 & 1 & 0.25 \\
\hline & Fauna Diversity & 0 & 2 & 0 & 0 & 2 & 0.50 \\
\hline & Wetland & 0 & 0 & 0 & 0 & 0 & 0.00 \\
\hline & Char land & 0 & 2 & 0 & 0 & 2 & 0.50 \\
\hline \multirow{5}{*}{$\begin{array}{l}\text { Socio- } \\
\text { Cultural } \\
\text { Compo- } \\
\text { nents }\end{array}$} & Landscape & 0 & 0 & 0 & 0 & 0 & 0.00 \\
\hline & Land use & 3 & 0 & 1 & 1 & 5 & 1.25 \\
\hline & $\begin{array}{l}\text { Health, Safety } \\
\text { and Hygiene }\end{array}$ & 0 & 1 & 0 & 0 & 1 & 0.25 \\
\hline & Economy & 4 & 0 & 1 & 0 & 5 & 1.25 \\
\hline & Accidents & 2 & 0 & 2 & 0 & 4 & 1.00 \\
\hline \multicolumn{2}{|c|}{$\begin{array}{l}\text { cording to Environmental } \\
\text { Factors }\end{array}$} & 18 & 12 & 10 & 5 & \multirow{2}{*}{\multicolumn{2}{|c|}{ IF $=0.80($ Acceptable $)$}} \\
\hline \multicolumn{2}{|c|}{ Average } & 1.29 & 0.86 & 0.71 & 0.36 & & \\
\hline
\end{tabular}


The average assessment effect of cumulative impact factors on environmental components is 0.80 . So, in the operation and maintenance stage the overall impact of different project activities on physical, biological and socio-economic components is low. In the construction stage the vibration, flora and fauna diversity, land use pattern and health, safety and hygiene will be mainly affected by different construction activities. So, during construction the authority should be aware of it and take proper mitigation measure for reducing the harmful impact.

\subsection{Final result of matrix evaluation}

"In the preconstruction stage, overall effect of different activities on the various environmental components is tolerable and these effect in both construction and operation stage is low. So, the project is accepted.'

\subsection{Mitigation measures}

1) Use of fallow land and prepare them for cultivation

The fallow land of the project area can be used for production. The low land can be filled by dredged materials. Then, Theses land can be used for agriculture and hose stead area. If these fallow lands can be used for cultivation the crop production will be increased. Beside this, the impact of agricultural land loss as well as production loss due to the implementation of this project will reduced.

\section{2) Preservation of wet land and create new}

The existing wet lands will have to be preserved. Beside this, some new wet lands will have to be dug. Due to river training work and filling of flood plains and pond the natural aquatic habitat will be hampered. This impact cannot be removed but by creating new wetlands the environmental impacts can be reduced.

\section{3) Tree plantation}

Due to site preparation and other preconstruction activities many trees will be have to be cut which cannot be prevented. This deforestation process has a negative impact on environment. This impact can be reduced through reforestation program. Tree plantation program can be implemented in both sides of road and river.

4) Conservation of ecological resources

During site preparation, many wet lands and floodplains will have to be filled which have a negative impact on ecological resources. Some endangered species such as some fish species, reptile and amphibians will face the threat of extinction due to these activities. To preserve these extinct species, new wet lands and other habitats will have to be prepared and reducing the use of the critical areas as far as possible.

5) Alternative Livelihood for displaced person At the time of pre-construction activities, the boatman, street hawker of the ferry and the shopkeepers of the ferry Ghat will lose their livelihood. In this regard, these occupationally displaced people due to project activities can be transferred into alternative livelihoods for the measurement of their subsistence.

Construction Stage

6) Choose the pile construction period with the exception of breading time

A construction window is proposed for piling schedule to reduce the impact of fish migration. The construction period must be chosen with the exception of breeding time of differently fishes. The breading time of most of the fishes should be avoided.

7) Reduce the impact on porpoise

The vibration and noise of the construction activity has a significant negative impact on porpoise production. For reduction of vibration and noise the percent method can be applied and reduce sound during activity by using high technology.

8) Making open ground for migratory birds

For construction activity the char land and flood plain will be used. At present this land are used by migratory birds in winter season. As they will be used for construction purpose, some lands will have to be prepared for roaming of the winter migratory birds. In this regard, some open fields can be created for roaming of the birds near the char land.

9) Prevent the mixing of waste and other materials with water

Due to the mixing of construction materials, different wastes and construction water the water becomes polluted. Mixing of construction water and the materials with river water will have to be reduced because the turbidity of river water happens the breading of fishes. All the waste will have to be properly disposed to prevent the mixing with water.

\section{0) Reduction of noise}

Due to the high density of vegetation coverage the local community will not be very much affected by the noise of construction activity. But the construction worker will be affected by it. To reduce this impact construction worker may use "earplug" in their ear.

11) Reduction of pollutant in the air

Air is mainly polluted because of dust and odor. Dust is generated mainly for handling of different construction materials which can be prevent the emission of odor by the proper disposal of wastes. Approach road

12) Tree plantation in booth sides of road

During the construction of approach road many trees will have to be cut which have a significant impact on environment. To reduce this impact planting trees in booth side of the approach road will be very fruitful.

13) Use of fallow land

Due to construction of approach road some agriculture land will have to be consumed. To reduce this loss, the fallow land of the area can be used for agriculture, which will help to balance the agricultural production.

14) Prepared low land for fish cultivation

Some ponds can be dug for fish cultivation. Beside this, by reserving water in the low land different types of fish can be cultivated which will reduce loss of fish production.

15) Reduce the emission of pollutant

During the melting of bituminous, different gases will be emitted such as $\mathrm{CO}, \mathrm{SO}_{2}$ etc. which will pollute the air. To reduce this impact these harmful gases should be neutralized. Beside this, the emission of odor will have to be prevented by the proper disposal of wastes.

Bridge end facility

16) Reduce the impact of noise

During the utilization of different materials and several activities such as wielding a huge noise will be created. Because of the high vegetation density, the local people will not be affected but for the protection of construction workers earplug and some other noise protection can be used.

17) Reforestation

Due to the construction of different bridge end facilities some lands will have to be acquired. For this land acquisition some forest lands will be destroyed. To mitigate this loss a reforestation program will have to be happened.

\section{8) Preservation of fish habitat}

During construction of the bridge end facilities, some ponds and other lands will be used. For the preservation of fish habitat new ponds and others, wetland will be dug. Beside this, during construction the wetland will have to be avoided.

\section{9) Produce high yield variety}

Due to the construction activity mainly, agriculture lands will be used. To mitigate the impact of agriculture production loss the farmers can be trained with modern technique such as they will be taught about HYV crops so that the production will not be hampered.

\section{0) Modification of cultivation system}

Due to the construction activity many agriculture lands will be used for construction of yards. To mitigate the impact of this loss the farmers will have to be trained with modern techniques. The cultivation of different HYV crops will have to be practiced.

21) Maintain the air, water and noise quality 
For this purpose, the emission of dust and odor will have to be stopped. Mixing of waste and other materials with water will have to be prevented. To prevent the noise pollution some actions can use earplugs, muffler.

Some mitigation measures will be required after the operation and maintenance stage to reduce the negative effect.

Table 4: Operation and Maintenance Stage Mitigation Measures

\begin{tabular}{|c|c|c|}
\hline Mitigation Stage & \multicolumn{2}{|c|}{ Activities } \\
\hline \multirow{4}{*}{ Operation and maintenance stage } & a) & $\begin{array}{l}\text { Reduce the scouring pro- } \\
\text { cess }\end{array}$ \\
\hline & b) & Emission reduction \\
\hline & c) & Reduction of noise \\
\hline & d) & River Training works \\
\hline
\end{tabular}

\section{Conclusion and recommendation}

Environmental impact assessment identifies the potential positive and negative environmental, social and economic impacts of the project. The project will connect some vital southern regions such as Bhuphal, Dhasmina with the district city Patuakhali and the divisional city Barisal. The major negative Impacts of this project are loss of land and resettlement, loss of aquatic habitat, loss of trees, loss of agricultural lands, loss of agricultural production, loss of vegetation, potential impact on ecological resources, impact on fish migration, impact on porpoise, impact on migratory winter birds, impact on other endangered species, impact on surface water quality, noise generation from construction activities, impact on air quality, clearing of vegetation along the road corridors, impact on fisheries, loss of top soil, change in land use pattern. Positive impacts of this project during construction and maintenance are employment generation, vegetation, reuse of top soil, gender promotion, change in land use, and generation of employments are identified. Mitigation measures regarding the adverse impacts are use of fallow land and prepare them for cultivation, preservation of wet land and create new, tree plantation at both side of the approach road and service area, conservation of ecological resources, alternative livelihood for displaced person, provide compensation for resettlement, engage NGOs for implementation of resettlement plan, compensate the loss of crop production, encourage women participation in construction works, choose the pile construction period with the exception of breading time, reduce the impact on porpoise, making open ground for migratory birds, prevent the mixing of waste and other materials with water, reduction of pollutant in the air, establishment of sanctuary and char land visitor center, cover haul vehicles carrying materials, minimum grudging of char land and minimum disturbance to habitat, provide temporary noise barriers near the sensitive areas, use good quality vehicles, machineries and equipment, unused concrete should not dispose into the river water, ensure that dredging materials do not contain heavy metals, proper handling of contaminated soil, modification of cultivation system, provide appropriate drainage structure at appropriate locations to avoid local flooding, emergency response plan is prepared for road accidents, regular monitoring of morphological change of river at the bridge location. By evaluating different environmental impacts, it can be said the negative due to this project is not so high. So, the project can be implemented. Some recommendations of the study are as follow-

- For constructing the bridge use the shortest distance of the river

- Avoiding forest land, agricultural land and other settlements as far as possible

- Conservation of flora and fauna diversity

- Activities which are harmful for the breeding of different fish species should be avoided

- Complete all resettlements activities before the starting of the project activity.

\section{References}

[1] Ahammed, R\& Harvey, N. (2004) Evaluation of environmental impact assessment procedures and practice in Bangladesh, Impact Assessment and Project Appraisal, 22:1, 63-78, https://doi.org/10.3152/147154604781766102.

[2] DoE, (1997). EIA Guideline for Industries, Department of Environment, Ministry of Environment and Forest, Govt. of the People's Republic of Bangladesh.

[3] ECA (1995). The Bangladesh Environment Conservation Act 1995 , (Act no. 1 of 1995) Department of Environment, Ministry of Environment and Forest, Govt. of the People's Republic of Bangladesh.

[4] ECR (1997). The Environment Conservation Rules 1997, Department of Environment, Ministry of Environment and Forest, Govt. of the People's Republic of Bangladesh.

[5] Environmental Impact Assessment: Theory and Practice, Unwin Hyman: Boston. pp. 129-142. Modak P.and Biswas, A. K., (1999). Conducting environmental impact assessment for developing countries, Tokyo: United Nations Press

[6] Food and Agriculture Organization of the United Nations (FAO), (1996). Environmental impact assessment and environmental auditing in the pulp and paper industry (Working paper 129). Rome.

[7] Hasan I, Majumder S.I, Islam M.K, Rahman M.M, Hawlader N.H, Sultana I. (2017). Assessment of Community Capacities against Cyclone Hazard to Ensure Resilience in South Central Coastal Belt of Bangladesh. International Journal of Ecological Science and Environmental Engineering. Vol. 4, No. 1, pp. 1-14.

[8] Kabir, S.M.Z., and Momtaz, S., (2011). Implementation of environmental mitigation measures and effective EIA practice in Bangladesh: a study of three-development project, International Journal of Arts \& Sciences, 4(27):1-18.

[9] Kabir, S.M.Z., and Momtaz, S., (2012). The quality of environmental impact statements and environmental impact assessment practice in Bangladesh, Impact Assessment and Project Appraisal, 30(2):94-99. https://doi.org/10.1080/14615517.2012.672671.

[10] Kabir, S.M.Z., and Momtaz, S., (2013). Fifteen years of environmental impact assessment system in Bangladesh: current practice, challenges and future directions, Journal of Environmental Assessment Policy and Management, 15(4):1-30. https://doi.org/10.1142/S146433321350018X.

[11] Majumder SI, Hasan I, Mandal S, Islam M.K, Rahman M.M, Hawlader N.H, Sultana I. (2017). Climate Change Induced Multi Hazards Disaster Risk Assessment in Southern Coastal Belt of Bangladesh. American Journal of Environmental Engineering and Science. Vol. 4, No. 1, pp. 1-7.

[12] Islam M.S, Majumder S.I, Hasan I, Yeasmin T, Islam M.K, Rahman M.M, Hawlader N.H, Sultana I, (2017) Environmental Impact Assessment of Lebukhali Bridge Construction Project over the River of Paira, Bangladesh, Journal of Energy, Environmental \& Chemical Engineering. Vol. 2, No.1, pp.10-15. 